Click www.researchjournal.co.in/online/subdetail.html to purchase.

A REVIEW

International Journal of Agricultural Engineering | Volume 10 | Issue 2 | October, 2017 | $655-663$

$\Rightarrow$ e ISSN-0976-7223 $\square$ Visit us : www.researchjournal.co.in $\square$ DOI: 10.15740/HAS/IJAE/10.2/655-663

\title{
Energy production from biomass
}

\section{RAGHUVIRSINH PARMAR, ASEEM VERMA, RITU DOGRA AND URMILA GUPTA}

See end of the Paper for authors' affiliation

Correspondence to :

RAGHUVIRSINH PARMAR

Department of Farm

Machinery and Power

Engineering, Punjab

Agricultural University, LUDHIANA (PUNJAB) INDIA

Email : parmarraghuvir-

fmpe@pau.edu
- ABSTRACT : The most common form of biomass used as renewable energy and it is widely used. Recently more attention has been focused on identifying suitable biomass species, which can provide high-energy outputs, to replace conventional fossil fuel energy sources. The type of biomass required is largely determined by the energy conversion process and the form in which the energy is required. To provide energy the use of biomass has been mainly to the development of civilization. Recently pressures on the global environment have led to calls for an increased use of renewable energy sources. Biomass is one major potential source of renewable energy and the conversion of plant material into a suitable form of energy, usually electricity or as a fuel for an internal combustion engine, can be achieved using a number of different routes, each with specific pros and cons. A brief review of the main conversion processes is presented, with specific regard to the production of the fuel.

- KEY WORDS : Biomass, Energy conversion, Process, Technology

- HOW TO CITE THIS PAPER : Parmar, Raghuvirsinh, Verma, Aseem, Dogra, Ritu and Gupta, Urmila (2017). Energy production from biomass. Internat. J. Agric. Engg., 10(2) : 655-663, DOI: 10.15740/HAS/IJAE/10.2/655-663. 